\title{
Kuntouttava työote 2.0 - Terapeuttilähtöisyydestä hoitajakeskeiseen kuntoutumista edistävään hoitotyöhön
}

\author{
Heidi Siira, Sinikka Lotvonen, Kaisa Saarela, Helvi Kyngäs
}

\section{Tausta}

Vanhus- ja voimavaralähtöinen, ibmiskeskeinen, yksilöllinen ja kuntoutumista edistävä ovat laatusanoja, joita vanhuspalvelujärjestelmän toimijoiden strategiat, tuotekuvaukset sekä palveluja laatulupaukset vilisevät. Toteutuvatko ne aidosti arjen toiminnoissa vai jäävätkö vain palveluntuottajan missioon ja visioon kirjoitetuksi sanahelinäksi? Hoitotyön arkipäivässä, etenkin kotihoidossa, eletään työajan riittävyyden ja työn sisällöllisten vaatimusten ristipaineessa työntekijöiden sinnitellessä työhyvinvoinnin ja jaksamisen äärirajoilla. Kuntoutumista edistävä hoitotyö saattaa tuntua hoitajasta yhdeltä ympäripyöreältä lisähaasteelta muutenkin työntäyteisessä arjessa. Työntekijöiden vaihtuvuus ja alanvaihto ovat rasite kestävälle ja laadukkaalle kotihoidolle, mutta sitä vielä vakavampi uhka on, että kotihoidon iäkkäät asiakkaat tulevat kohdatuiksi, kuulluiksi ja hoidetuiksi pinnallisesti ja sairauslähtöisesti, jolloin heidän voimavaransa jäävät huomioimatta ja asioita tehdään heidän puolestaan.

Sosiaali- ja terveysministeriön strategiat, laatusuositukset sekä niin sanottu vanhuspalvelulaki painottavat ikääntyneiden toimintakyvyn tukemista, itsenäisen elämän tärkeyttä ja kuntoutumista edistävän hoitotyön merkitystä (Laki ikääntyneen väestön... 2012; STM 2017; STM 2018). Kuntoutumista edistävän hoitotyön tulisi toteutua nykyistä suunnitelmallisemmin ja tavoitteellisemmin, jotta se tukisi optimaalisesti ikääntyvien asiakkaiden fyysistä, psyykkistä ja sosiaalista toimintakykyä sekä lisäisi hyvinvointia ja elämänlaatua. Lisää resursseja ja rahaa ei vanhuspalveluihin ole lähitulevaisuudessa odotettavissa koronakriisin aiheuttamassa yhteiskuntaa kurittavassa taantumassa. Uudenlainen ajattelu ja ajattelutavan, jopa paradigman, muutos on tarpeen, jotta kuntoutumista edistävä hoitotyö voi toteutua.

Koronaviruspandemia ei tyynnytä maailmanlaajuista harmaata tsunamia ja väestön vanhenemista. Vähintään 60-vuotiaita oli 13 prosenttia maailman ja 25 prosenttia Euroopan väestöstä vuonna 2017 (Nikolich-Ž ugich ym. 2016; YK 2017). Suomessa 65 vuotta täyttäneitä on tällä hetkellä noin 22 prosenttia ja vuonna 2030 ennusteiden mukaan 25 prosenttia väestöstä. Vanhimpien ikäluokkien (80+) suhteellinen osuus vanhusväestöstä kasvaa eniten ja nopeimmin (Tilastokeskus 2019). Keskuudessamme on tulevina vuosikymmeninä myös yhä enemmän niin sanottuja vanhoja vanhuksia eli yli 90- ja yli 100-vuotiaita.

Tutkimusnäyttö kotiympäristössä tapahtuvasta kuntoutumista edistävän hoitotyön tehokkuudesta ja kustannusvaikuttavuudesta on kiistatonta (Sims-Gould ym. 2017). Tutkimusten mukaan kuntoutumista edistävällä hoitotyöllä ja sen onnistuneella johtamisella voidaan tukea hoitotyöntekijöiden työhön sitoutumista, työssä jaksamista ja työssä viihtymistä sekä työhyvinvointia (Vähäkangas 2010; Hjelle ym. 2018; Liaaen \& Vik 2019; Smeets ym. 2020). 
Lisäksi se tuo huomattavia säästöjä sosiaalija terveyspalveluiden tarjoajille asiakkaiden lisääntyneenä toimintakykynä ja hyvinvointina (Sims-Gould ym. 2017). Suomessa ikääntyneiden toimintakykyä on tutkittu paljon jo useiden vuosikymmenten ajan (Heikkinen ym. 2013), mutta kuntoutumista edistävän hoitotyön tutkimus on kansallisesti vähäistä. Etenkin kotona tapahtuvaa kuntoutumista edistävää hoitotyötä tulisi tutkia (Stenman 2020).

\section{Kuntoutumista edistävä hoitotyö tutkimuskohteena ja toimintana}

Kuntoutumista leimaava monialaisuus ja -tieteisyys tekee siitä haasteellisen mutta samalla ehtymättömän ja antoisan tutkimuskohteen. Kuntoutumista edistävä hoitotyö ei ole uusi asia. Kuntouttavasta työotteesta on puhuttu maailmalla 1980-luvulta lähtien, ja Suomessa siihen on alettu kiinnittää enenevästi huomiota 1990-luvulta lähtien. Australia, Tanska ja Kanada ovat edelläkävijöitä niin tutkimuksellisesti kuin asenteellisestikin. Kuntoutumista edistävä hoitotyö (reablement/rehabilitative care) on vähemmän intensiivistä, yksinkertaisempaa ja kustannuksiltaan halvempaa kuin sairaus- ja/tai vamma- sekä sairaalalähtöinen ja lääkärin määräämä, terapeuttien toteuttama kuntoutus, ja se ulottuu laajemmalle vanhuspalvelujärjestelmässä. Kuntoutumista edistävä hoitotyö perustuu kansainvälisen konsensuksen mukaan ikääntyneen toimintakyvyn arviointiin ja kuntoutumistavoitteiden laadintaan. Sen tulee toteutua edistämällä ja tukemalla ikääntyneen liikuntakykyä ja omatoimisuutta hoitotilanteissa. Kotiympäristön turvallisuus tulee kartoittaa ja huolehtia sopivien apuvälineiden hankinnasta. Kuntoutumista edistävän hoitotyön tavoitteena on tehokkaat, tulokselliset, kokonaisvaltaiset, moniammatilliset, ihmiskeskeiset ja tavoitteelliset kotipalvelut, jotka parantavat asiakkaan toimintakykyä ja tukevat itsenäistä elämää.
Hoitaminen on hoitotieteen ydin, ja kuntoutumista edistävää toimintaa hoitotieteen näkökulmasta tarkasteltaessa keskiössä on hoitohenkilöstön toiminta asiakkaan kotona ja elinympäristössä. Asiakaslähtöinen hoitotyö korostaa asiakkaan arvokkuuden tunteen säilymistä ja asiakkaan yksilöllisten tarpeiden ja toivomusten huomioon ottamista häntä koskevia päätöksiä tehtäessä. Kuntoutumista edistävän hoitotyön tunnistetaan pohjautuvan monialaiseen ja moniammatilliseen yhteistyöhön. Ihmistä, terveyttä, hoitotyötä ja ympäristöä tutkivalla hoitotieteellä on yhtä paljon annettavaa kuntoutumista edistävän hoitotyön käsitteelle kuin eri terapiatieteillä.

Siitä huolimatta, että pystymme teoreettisesti määrittelemään kuntoutumista edistävän toiminnan ja hoitotyön, vaatii käytännön toteutus ja vastuunjako selkiyttämistä. Vanhuspalveluissa ikääntyneitä hoitavat yleensä lähihoitajat moniammatillisessa tiimissä, johon kuuluu usein myös sairaanhoitaja ja fysioterapeutti. Kuntoutumista edistävä hoitotyö ei ole yksin kenenkään tehtävä, vaan kaikkien yhteinen vastuu on ohjata ja motivoida asiakasta edistämään toimintakykyään ja hyvinvointiaan. Kuntoutumista edistävässä hoitotyössä ei tarvitse pelätä hierarkiaa ja sitä, että astuu jonkun "alueelle" tai "varpaille".

\section{Kuntoutumista edistävä hoitofilosofia ja muuttuva paradigma}

Kuntoutumista edistävässä hoitotyössä on jo vuosikymmeniä sitten siirrytty puolesta tekemisestä (doing for) yhdessä tekemiseen ja tavoiteltu asiakkaan itsenäisyyttä ja voimavaralähtöisyyttä arkiaskareissa. Silti kuntoutumista edistävää toimintaa leimaa doing to -vivahde, joka ilmenee esimerkiksi asiakkaille ennakkoon ja valmiiksi laadittuina ohjelmina ja aktiviteetteina, joita heidän odotetaan noudattavan ja toteuttavan itsenäisesti ja oma-aloitteisesti. Nyt ja tulevaisuudessa kuntoutumista edistävän 
hoitotyön tulee olla yhä enemmän tavoitteellista työskentelyä ja toimimista yhdessä asiakkaan kanssa (working with). Tällöin saavutetaan tavoitteita, jotka asiakkaat itse näkevät arvokkaina, merkityksellisinä ja tavoittelemisen arvoisina.

Kuntoutumista edistävän hoitotyön toteutuksessa keskeiseksi mielletään omatoimisuuteen kannustaminen ja fyysiseen aktiivisuuteen ohjaaminen. Se, että arjessa ei tehdä asioita asiakkaan puolesta, on erittäin hyvä lähtökohta mutta ei riitä yksistään. Kuntoutumista edistävässä hoitotyössä pitäisi malttaa pysähtyä myös mielen tasolla, kuunnella asiakasta ja kohdata hänet kiireettä ja ainutkertaisena yksilönä. Kotihoidossa hyödynnetään monia sinänsä työtä helpottavia ja tiedonkulkua sujuvoittavia mobiilisovelluksia, sensoreita ja älylaitteita. Digitalisoituneessa maailmassa yhä tärkeämpää ja merkityksellisempää on aika, jonka vietämme asiakkaan kanssa fyysisesti samassa tilassa, kasvotusten. Hoitajan tulisi silloin kyetä olemaan täysin läsnä ja vain ja ainoastaan asiakastaan varten. Tove Jansson opasti meitä Muumilaakson Näkymättömän Ninnin tarinassa näkemään ja kohtaamaan toisemme arvostaen - niin, että tulemme hiljalleen näkyviksi toisillemme. Myös vanhusväestömme soisi tulla laadukkaan kuntoutumista edistävän hoitotyön kautta näkyväksi, sillä turhan usein tästä hyvin heterogeenisesta ihmisryhmästä puhutaan kielteiseen sävyyn massana, josta tehdään yksioikoisia yleistyksiä. Kariniemi ja kumppanit (2020) korostivat tutkimuksessaan asiakkaan kuulluksi ja kohdatuksi tulemisen tärkeyttä kotihoidossa erityisesti siitä syystä, että niiden avulla voidaan havaita asiakkaan yksilölliset tarpeet ja elämäntilanteet sekä arvioida hänen tarvitsemaansa yksilöllistä tukea ja palveluntarvetta.

Terapeuttikeskeisistä ja -lähtöisistä interventioista on tulevaisuudessa siirryttävä yhä enemmän kohti yksilöllisesti suunniteltua ja hoitotyön arkeen integroitua toimintaa. Hoitajien rooli on keskeinen ja korvaamaton ennaltaehkäisyssä, ikääntyvien asiakkaiden motivoinnissa, riittävien harjoituskertojen ja tois- tojen varmistamisessa sekä tavoitteiden asettamisessa ja seuraamisessa. Liian usein ajatellaan virheellisesti, että fysioterapeutin käynti kerran viikossa 15 viikon ajan on riittävää kuntoutusta ikääntyvälle henkilölle. Ajattelutavan muutosta tarvitsevat asiakkaatkin. Työ kuntoutumisen ja toimintakyvyn säilymisen eteen täytyy tehdä itse - vanhanakin.

Kuntoutumista edistävässä hoitotyössä tulee siis antaa entistä painavampi arvo sille, mikä ihmisiä todella motivoi työskentelemään tavoitteidensa eteen ja käyttämään voimavarojaan maksimaalisesti. Kuntoutumista edistävän hoitotyön ammattilaisilta tällainen paradigman muutos vaatii vain hieman nykyistä enemmän mielikuvitusta ja luovuutta. (Newton 2012.) "Kaikkea kaikille"-periaate ei toimi kuntoutumista edistävässä hoitotyössä. Sen sijaan on käytettävä aikaa asiakkaaseen tutustumiseen ja hänen sisäisen motivaationsa herättämiseen, mikä onnistuu vain tutustumalla asiakkaaseen yksilönä ja yhdessä hänen kanssaan tavoitteita asettamalla. Uusin teknologia voi motivoida yhtä ikääntyvää henkilöä liikkumaan enemmän, kodin lähelle avattu uusi kahvila toista ja kuoroharrastus kolmatta. Kuntoutumista edistävä hoitotyö tuleekin nähdä eräänlaisena yksilöllisenä ongelmanratkaisuna - kuten kuntoutustoiminta yleensäkin (Wade 2020). Motivaatio ja sen herättäminen on tie onnistumiseen (Newton 2012). Motivaation herättäjänä voi toimia vanha japanilainen viisaus ikigai; se viittaa asioihin, jotka tekevät elämästä elämisen arvoisen (Nakanishi 1999). Saadakseen selville ja pystyäkseen hyödyntämään ikääntyvän asiakkaansa ikigaita kuntoutumista edistävässä hoitotyössä hoitajan tulee tuntea asiakkaansa ihmisenä ja olla hänestä kiinnostunut. Hoitajan tulee tuntea myös itsensä sekä tunnistaa ja pohtia omaa vanhuskäsitystään ja arvomaailmaansa kuntoutumista edistävän hoitotyön pohjana. Vanhuspalveluyksiköiden työyhteisöjen hoitokulttuuri ja yksittäisten hoitajien hoito- ja kuntoutusfilosofia rakentuvat pohjimmiltaan hoitajien ihmis- ja vanhuskäsitykseen sekä arvomaailmaan. Hoitajan arvot ja vanhuskä- 
sitys välittyvät vuorovaikutuksessa vanhusten kanssa, tavanomaisissa askareissa ja tilanteissa - myös siinä, miten hän toteuttaa kuntoutumista edistävää hoitotyötä.

Kuntoutumista edistävälle hoitotyölle ei ole tiukkoja raameja, vaikka lähtötilannearvio, tavoitteenasettelu, seuranta ja arviointi ovat ensiarvoisen tärkeitä. Kuntoutumista edistävässä hoitotyössä saa olla luova ja hyödyntää persoonaansa ja erityisosaamistaan. Hoitaja voi myös oppia asiakkaaltaan tai voimaantua asiakkaan toiminnan seurauksena. Asiakkaan hoitajalle harmonikalla soittama kappale kotihoitokäynnin yhteydessä saattaa pysäyttää hoitajan kiireisenä arkipäivänä ja muistuttaa hetkessä elämisen ja kohtaamisen tärkeydestä. Asiakas puolestaan voi nauttia hoitajan lapsen askartelemasta piirroksesta tai käsin koristelemasta piparkakusta. Kuntoutumista edistävä hoitotyö voi siis luoda voimaannuttavia siltoja ihmisten välille. Hoitajan oma ikigai näyttäytyy kuntoutumista edistävän hoitotyön resurssina,jota hän voi luovasti ja ennakkoluulottomasti hyödyntää asiakkaidensa kanssa toteuttaessaan kuntoutumista edistävää hoitotyötä. Kuntoutumista edistävä hoitotyö tekee työstä mielekästä, päivistä vaihtelevia ja antaa onnistumisen iloa sekä hyvää mieltä kaikille osapuolille - vaikka työ olisikin kiireistä ja vaativaa aikataulullisesti ja logistisesti.

Kuntoutumista edistävä hoitotyö ei siis vaadi toteutuakseen lisäresursseja vaan vain olemassa olevien voimavarojen oikean- ja uudenlaista käyttöä. Hyvä lähtökohta on, että kuntoutumista edistävän hoitotyön yhteydessä ei puhuta sängyssä elävistä asiakkaista, vaikka he olisivat kuinka hauraita tahansa. Kuntoutumista edistävä hoitotyö tekee elämästä elämisen arvoista vielä sittenkin, kun muistisairaus on edennyt viimeiseen vaiheeseen tai yksilön elämänkaari on päättymässä. Hyväkuntoisen kotona asuvan ikääntyneen kohdalla kuntoutumista edistävä, ehkäisevä hoitotyö voi toteutua asukastuvalla digitaalisten pelien avulla järjestettyjen ryhmäliikuntaolympialaisten muodossa. Palvelukotiin muuttaneella ikääntyvällä henkilöllä kuntoutumista edistävä hoitotyö voi olla yksilöllisen ja tavoitteellisen alaraajojen lihasvoimaharjoitteluohjelman toteutus ja seuranta sekä monipuolinen sosiaalinen kanssakäyminen muiden talon asukkaiden kanssa. Hoivaosastolla kuntoutumista edistävä hoitotyö voi toteutua hoitajan hellänä ja välittävänä kosketuksena, mieliruoan nauttimisena tai vuodenaikaan sopivien kukkien tuoksuna. Kuntoutumista edistävällä hoitotyöllä tavoitellaan paitsi toimintakykyistä ja onnistunutta vanhenemista myös onnellista ja omannäköistä vanhuutta.

\section{Aito yhteistyö ja laaja-alaisuus}

Pohdinnan paikka on, miksi kuntouttava työote ja kuntoutumista edistävä hoitotyö ovat juuttuneet vuosikymmeniksi paikoilleen ja muuttuneet sanahelinäksi, jonka tavoitteellinen toteutus, seuranta ja arviointi ontuu. Syy voi osittain olla terapeuttikeskeisyydessä ja siinä, että kuntoutumista edistävä hoitotyö saatetaan nähdä arjen toiminnoista erillisinä ja irrallisina toimenpiteinä, viikko-ohjelmina ja liikuntasuoritteina. Ulkoapäin ohjattuna ja annettuna kuntoutumista edistävä hoitotyö ei saavuta tavoitteitaan yhtä hyvin kuin aidosti asiakkaan kanssa hänen yksilöllisistä lähtökohdistaan suunniteltu, arvioitu ja toteutettu toiminta. Kaikkien kuntoutumista edistävään hoitotyöhön osallistuvien hoitajien ja terapeuttien tulee kokea tulleensa kuulluksi, nähdyksi ja kohdatuksi moniammatillisessa tiimissä sekä hoitotyön esihenkilöiden ja -johtajien toimesta. Voimaantuessaan hoitohenkilökunta ja ikääntyvät asiakkaat ovat kuin Näkymätön Ninni, joka muumiperheen ymmärtävässä ja yksilöllisyyden sallivassa ympäristössä hiljalleen tuli näkyväksi sekä kuulluksi ja aidosti kohdatuksi - omana arvokkaana itsenään.

Fyysisen toimintakyvyn osuus itsenäisessä päivittäisistä toiminnoista suoriutumisessa sekä toki psyykkisessä ja sosiaalisessa toimintakyvyssä on kiistaton, mutta kuntoutumista edis- 
tävän hoitotyön mieltäminen vain fyysistä toimintakykyä edistäväksi saattaa olla epäedullista ja johtaa vastuun siirtoon terapeuteille. Kuntoutumista edistävä hoitotyö on kaikkien vanhuspalvelujärjestelmän toimijoiden yhteisellä vastuulla. Kun kaikki asianosaiset tekevät vähän, teemme yhdessä lopulta todella paljon - ja saamme aikaan merkittäviä tuloksia, kuten ikääntyneiden toimintakyvyn paraneminen, hoitohenkilöstön työhyvinvoinnin lisääntyminen ja palvelujärjestelmän kustannussäästöt.

Gerontologisen hoitotieteen näkökulman tuominen kuntoutumista edistävään toimintaan ja sen lähtökohdaksi on uusi paradigma, jota kuntoutumista edistävän toiminnan tehokas johtaminen ja käytännön toteutus vaatii. Aiempi terapeuttikeskeinen ja -johtoinen toiminta ei ole saavuttanut koko potentiaalia,

\section{Kirjallisuus}

Heikkinen E, Era P, Heikkinen RL, Rantakokko M, Ruoppila I, Suominen H. Ikääntymistä ja toimintakykyä koskevien tutkimusten tavoitteet, asetelmat ja toteuttaminen. Gerontologia 2013; 27(4):341-354.

Hjelle KM, Skutle O, Alvsvåg H, Førland O. Reablement teams' roles: a qualitative study of interdisciplinary teams' experiences. J Multidiscip Healthc 2018;3(11):305-16. https://doi.org/10.2147/JMDH.S160480

Kariniemi K, Siira H, Kyngäs H, Kaakinen P. "Vanhakin on ihminen": Ikääntyneiden kokemuksia vahvuuksistaan, voimavaroistaan ja kotihoidosta. Gerontologia 2020;34(1):25-42. https://doi.org/10.23989/gerontologia.80436

Laki ikääntyneen väestön toimintakyvyn tukemisesta sekä iäkkäiden sosiaali- ja terveyspalvelujen järjestämisestä 28.12.2012.

Liaaen J, Vik K. Becoming an enabler of everyday activity: health professionals in home care services experiences of working with reablement. Int J Older People Nurs 2019;14:e12270. https://doi.org/10.1111/opn.12270

Nakanishi N. Letter from...Japan. "Ikigai" in older Japanese people. Age Ageing 1999;28:323-324. joka kuntoutumista edistävällä toiminnalla on ikääntyvälle väestölle tarjota. Oulun yliopistoon perustettu hoitotyön tutkimus- ja osaamiskeskus GeroNursing Centre (GNC) tiivistää ja tuottaa tieteellistä tutkimusnäyttöä ikääntyvien kuntoutumista edistävän hoitotyön vaikuttavuudesta ja merkityksellisyydestä. GNC haluaa haastaa vanhuspalvelujärjestelmän toimijat puhaltamaan yhteen hiileen kuntoutumista edistävän hoitotyön kehittämiseksi kohti arvokasta, onnellista ja toimintakykyistä vanhuutta sekä mielekästä, kutsuvaa ja palkitsevaa vanhustyötä.

\section{Yhteydenotto:}

Heidi Siira, ft, TtM, TtT-opiskelija, yliopisto-opettaja

GeroNursing Centre, Oulun yliopisto

Newton C. Personalising reablement: inserting the missing link. Work Older People 2012; 16(3):117-21.

Nikolich-Žugich J, Goldman DP, Cohen PR, Cortese D, Fontana L, Kennedy BK ym. Preparing for an aging world: engaging biogerontologists, geriatricians, and the society. J Gerontol A Biol Sci Med Sci 2016;71(4):435-44. https://doi.org/10.1093/gerona/glv164

Sims-Gould J, Tong CE, Wallis-Mayer L, Ashe MC. Reablement, reactivation, rehabilitation and restorative interventions with older adults in receipt of home care: a systematic review. JAMDA 2017;18(8):653-63. https://doi.org/10.1016/j.jamda.2016.12.070

Smeets RGM, Kempen GIJM, Zijlstra GAR, Rossum E van, de Man-van Ginkel JM, Hanssen WAG, Metzelthin SF. Experiences of home-care workers with the 'Stay Active at Home' programme targeting reablement of community-living older adults: an exploratory study. Health Soc Care Community 2020;28:291-9. https://.doi.org/10.1111/hsc.12863

Stenman P. Iäkkäiden hoitotyössä toimivan henkilöstön kokemuksia työtyytyväisyydestä ja toi- 
mintaympäristöstä kinestetiikan käyttöönoton aikana. Väitöskirja. Acta Universitatis Ouluensis D Medica 1581. Oulu: Oulun yliopisto, 2020.

STM. Laatusuositus hyvän ikääntymisen turvaamiseksi ja palveluiden parantamiseksi 2017-2019. Sosiaali- ja terveysministeriö. Julkaisuja 2017:9. Internet: http://urn.fi/URN:ISBN:978-952-00-3960-8 (viitattu 30.4.2020).

STM. Eheä yhteiskunta, kestävä hyvinvointi. Sosiaali ja terveysministeriön tulevaisuuskatsaus. 2018. Internet:

http://urn.fi/URN:ISBN:978-952-287-596-9 (viitattu 30.4.2020).

Tilastokeskus. Väestöennuste. 2019. Internet: https://www.stat.fi/til/vaenn/2018/ vaenn_2018_2018-11-16_tie_001_fi.html (viitattu 30.4.2020).
Vähäkangas P. Kuntoutumista edistävä hoitajan toiminta ja sen johtaminen pitkäaikaishoidossa. Acta Universitatis Ouluensis D 1060. Oulu: Oulun yliopisto, 2010.

Wade DT. What is rehabilitation? An empirical investigation leading to an evidence-based description. Clinical rehabilitation 2020;34(5):571-83. https://doi.org/10.1177/0269215520905112

YK. Yhdistyneet kansakunnat. World population prospects: the 2017 revision. 2017. Internet: https://www.un.org/development/desa/publications/world-population-prospects-the-2017-revision.html (viitattu 30.4.2020). 